\title{
Understanding the Nexus between Conflict, Displacement, and Schooling: A Case Study of IDPs in Pakistan
}

\author{
Anayat Ullah, Karim Khan, and Hamid Mahmood
}

\begin{abstract}
More than fifteen years of intense internal armed conflict has made Pakistan home to one of the largest populations of internally displaced persons (IDPs). This article investigates the impact of conflict on socioeconomic well-being through measuring changes in post conflict levels of schooling, livelihood, and income, and also seeks to understand the challenges faced by IDPs from the Federally Administered Tribal Areas located in Jalozai Camp, Khyber Punkhtoonkhwa (KP). The results of a survey analysis indicate significant gaps in educational attainment due to displacement and this impacts socioeconomic well-being.
\end{abstract}

Keywords conflict, displacement, IDPs, Jalozai Camp, Khyber Punkhtoonkhwa, Pakistan

\section{Introduction}

The devastating impact of conflict on a population's socioeconomic well-being has been well recorded (Justino 2010). Conflict in the current global context has been recognized as one important barrier in socio-economic development, and it negatively impacts education (Collier 2007). This is usually seen in the form of a population being displaced, destruction of capital, decreases in the level of schooling, and impacts on livelihood and income (UNHCR 2009).

It is estimated that half of all school-aged children in the world live in conflict prone areas. Children's schooling has been directly and indirectly impacted through loss of income opportunities, livelihood, property, and infrastructure, and child labor also prevents them from attaining an education (Dryden-Peterson 2010; UNESCO 2013). Conflict is also associated with population displacement which adversely affects both formal and informal schooling (UNESCO 2011). In fact, it has been verified that there is high dropout rate among children in developing countries with only 65 percent children 
finishing primary school due to conflict (Akresh and De Walque 2008). Donors have been providing major support to conflict areas to alleviate these problems and improve educational infrastructure for IDPs, mainly at the primary school level rather than the secondary and tertiary levels despite the fact that secondary education has suffered a rapid decline (Shemyakina 2007; Swee 2009; UNHRC 2009; Shields and Paulson 2014).

This article investigates the impact of conflict on education, at both the primary and secondary levels, on relevant socioeconomic indicators by surveying internally displaced persons (IDPs) from the Federally Administered Tribal Areas (FATA). The FATA region comprises of seven agencies (Bajaur, Mohmand, Khyber, Orakzai, Kurram, North and South Waziristan agencies) and six frontier regions (FR) (FR Peshawar, FR Kohat, FR Bannu, FR Lakki Marwat, FR Tank, and FR Dera Ismail Khan). The IDPs living in Jalozai Refugee Camp in Nowshera, Khyber Punkhtoonkhwa (KP) mostly come from the Khyber, Bajaur, and Mohmand agencies. The article also highlights the barriers and challenges faced by IDPs and provides recommendations for rehabilitating and providing a sustainable living to this displaced population.

\section{Literature Review}

The socio-economic impact of conflict on a community can be significant and continual in the form of injuries, insecurity, loss of income, loss of infrastructure, displacement from home, a negative impact on health and education, and the overall deterioration of society. One important impact is loss of human capital in the form of reduced investment in education resulting in a higher dropout rate; this may sustain the poverty trap, result in a loss of income opportunities, as well as effect labor market outcomes and economic performance (Mincer 1974).

Over the last two decades, it is estimated that more than 26 million people were internally displaced due to emergency situations out of which 50 percent are children (UNICEF 2009). Education is an important element for integrating a community affected by conflict as it can positively and significantly impact income and social capital across social groups, and can play an equalizing role between the genders (Mooney and French 2005).

The initial impact of conflict is usually seen in the context of a displaced population visible at both the micro and macro levels (Rice et al. 2006). In less developed and conflict prone states, international assistance and development funds are required in order to continue providing education to children if UNESCO's Education for All goal is to be reached (Brannelly et al. 2009). Previous studies have shown that during conflict and emergency situations, education usually receives little focus. This results in children dropping out of school, thus affecting the level of education of a society as well as the quality of 
services (Boyden and Ryder 1996; Crisp 2010).

The impact of insecurity and violence is not only restricted to sudden migration, but also leads to the destruction of soft and hard infrastructure, a reduced number of employment opportunities, constraints on resources, loss of skilled labor, shifting of resources to lower returns, and, more importantly, biased attitudes towards girls (Chamarbagwala and Moran 2011). For instance, in the case of the Zimbabwe civil war, boys were given more attention compared to girls with more investment in secondary education as evidenced by increased enrollment of boys at the secondary level. The civil war was followed by a drought, and on average children grew $3.4 \mathrm{~cm}$ less than if the conflict would have not taken place (Alderman, Hoddinott, and Kinsey 2006).

Similar findings are reported in the case of Rwanda where children have been mainly affected by armed conflict through loss of income opportunities and its significant impact on education (Akresh and Walque 2008). In the case of the Tajikistani civil war in the early 1990s, there was a significant decrease in the maximum level of education achieved by students, girls being especially affected at the secondary level (Shemyakina 2007). In cases of conflict, the progression of girls from primary to secondary school is low compared to boys, indicating recruitment preference of male children in light of concerns for earning income later in life (Guariso and Verpoorten 2013).

One of the important concerns of any community involved in conflict is with loss of property and income and decreases in the quality of schooling at both the primary and secondary levels. This is due to the slow recovery rate of education levels, income, and livelihood patterns among IDPs (Crisp 2010). It is estimated that the average recovery rate for primary school enrollment is longer than secondary enrollment in post conflict communities, indicating increases in income response distribution due to donor, community, and government support (Chen and Querol 2007).

The effect of war on level of education attainment, labor market outcomes, health standards, and livelihood prospects has been analyzed in the case of the Allied bombing of Germany during the Second World War. The results indicate that education at both the primary and secondary school levels was affected between 0.4 and 1.2 years with children on average growing one centimeter shorter than expected. The negative impact on income (6 percent) and livelihood (20 percent) indirectly contributed towards decreases in quality and achieved level of education (Akbulut-Yuksel 2009).

\section{Conflict and Displacement: Pakistan Perspective}

Pakistan has experienced a great deal of conflict since the partition of British India in 1947 with two armed conflicts shaping the country including disputes 
over Jammu and Kashmir and battles with Taliban factions/insurgents. Since 2004, an estimated 5 million people have been displaced due to different operations against insurgents operating in FATA (Chughtai 2013).

Pakistan is faced with multiple conflicts that have diverse regional and local causes with adverse and undesirable economic and social implications. This has significantly affected the lives of the community and, in particular, education has been severely affected in addition to other socio-economic indicators. There are five types of conflict in Pakistan based on the factor that led to their outbreak: geo-political, sectarian, religious/militant factions, nationalistic uprisings, and street crime. This includes conflict due to sectarianism (Shia vs. Sunni) in Hangu District, KP, geopolitical violence in Bajour Agency, FATA, religious conflict in Swat, KP, a nationalist movement in Balochistan Province, and conflict related to street crimes and ethnicity issues in Karachi, Sindh (Mustafa 2013).

Over the last decade, the Pakistani military has been engaged on multiple fronts in an effort to respond to these conflicts which have also resulted in the internal displacement of some populations, mainly those living in FATA. Currently there are many barriers to schooling in FATA, both from a demand and supply side perspective. The demand side factors usually include societal and household preferences/attitudes towards education, especially for girls' education, and livelihood issues. On the other hand, the supply side includes a lack of support from government and donor agencies in the area in terms of providing infrastructure and basic services for schools such as providing water, separate toilets for boys and girls, boundary walls, supplies for teachers, training facilities, and security (UNICEF 2013).

\section{Research Questions}

Understanding the impact of conflict induced displacement on education requires special attention because children tend to experience the impact of conflict differently compared to adults. An important question in this regard is affiliated with the evaluation of pre- and post-conflict/displacement situations and understanding the impact of conflict induced displacement on education both at the primary and secondary levels. Therefore, this study tries to examine the impact of conflict induced displacement on the IDPs of FATA at the Jalozai refugee camp by asking the following research questions. First, what is the impact of conflict induced displacement on education? Second, how do changes in income and livelihood impact education? And finally, what challenges and barriers do IDPs face? 


\section{Methodology}

This study quantitatively seeks to understand the perceptions of IDPs after displacement through the use of a survey questionnaire. The impact of conflict is understood by comparing the pre- and post-conflict situation in terms of education, income, livelihood, and challenges faced by IDPs. The survey was carried out in the Jalozai Refugee Camp located in Nowshera District, KP. Jalozai Camp also hosted millions of Afghan refugees after the Russian invasion in 1979. Recently, large numbers of IDPs from FATA have been living in Jalozai Camp. IDPs living there are the most vulnerable people and have no accommodations, weak social networks, and low economic statuses, and lack the means to earn a living.

Primary data was collected in March and April 2015 during a field visit to Jalozai Camp. A sample of 200 households was selected out of 5,363 total displaced families through systematic random sampling and the data collected was analyzed using statistical software including Excel and SPSS in order to answer the above identified research questions.

The study divides children into two groups: primary school (children 5-11 years old) and secondary school (children 12-17 years old). Within the 200 households sampled for this study, there is a total of 668 school-age children with 369 children enrolled in primary schools and 97 students enrolled in secondary schools. The remaining 202 children had dropped out of school due to troubles resulting from their displacement from the troubled FATA. The respondents were asked questions to evaluate changes in the post-conflict environment including changes in socio-economic indicators and schooling.

\section{Survey Results}

The results of the survey can be understood through the lens of supply and demand. Secondary data is used to show the supply side, while household survey analysis was used for comprehending the post-conflict change affiliated with IDPs from the demand side. The Provincial Disaster Management Authority (PDMA) and International Rescue Committee (IRC) have found that 47.2 percent of the population of the camp comprises school-age children between the ages of five and seventeen, representing almost half of the population of the camp. Primary school children represent 30.3 percent of the total population while the secondary school group is 16.8 percent (PDMA and IRC 2015). Details of the camp population are presented in Table 1 .

In the camp, there are a total of ten temporary schools that have been built, eight of which are primary schools and the remaining two being secondary 
Table 1. Age Profile of IDPs in Jalozai Refugee Camp (\%)

\begin{tabular}{l|c|c}
\hline \hline \multicolumn{1}{c|}{ Age Group } & Male & Female \\
\hline $0-4$ & 13.0 & 10.3 \\
$5-11$ & 16.9 & 13.4 \\
$12-17$ & 10.3 & 6.5 \\
$18-60$ & 13.2 & 9.8 \\
60 -above & 3.5 & 3.2 \\
\hline Total & 56.9 & 43.1 \\
\hline
\end{tabular}

Source: PDMA and IRC 2015

Figure 1. Enrolment by Schooling Level and Gender

School Enrollment (\%)

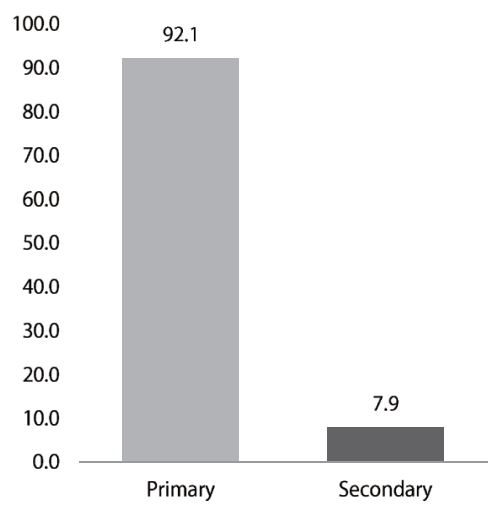

Gender ratio in Schooling (\%)

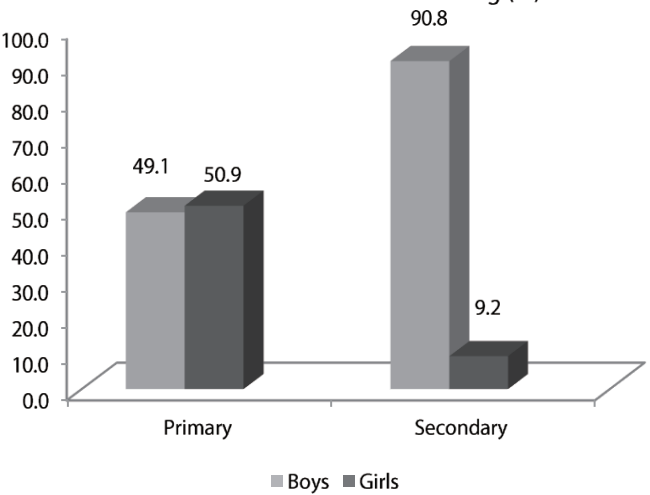

Source: PDMA and IRC 2015

schools. The total number of children currently enrolled in Jalozai Camp was $3,049,1,597$ boys and 1,452 girls. The total number of teachers was seventy with equal representation of male and female teachers in both primary and secondary schools (PDMA and IRC 2015). With respect to Figure 1, we can see that of the children enrolled in school, 92.1 percent were enrolled in primary school while 7.9 percent were enrolled in secondary school. Looking at the gender of these students, in primary school there was a near equal number of boys and girls, 49.1 percent being boys and 50.9 percent being girls. However, in secondary school, this ratio dramatically changes with 90.8 percent of secondary school students being boys. The reasons for this phenomenon of girls not continuing with their studies is likely cultural restrictions associated with Pardah (veil), early age marriages, and mobility issues due to cultural barriers for adult girls. For boys, household income is the main obstacle inhibiting them from attending secondary school. These results confirm those found in similar studies (Lai and Thyne 2007; 
Table 2. Enrolment Figures by Gender (\%)

\begin{tabular}{l|c|c|c|c}
\hline \hline \multirow{2}{*}{ Age Groups } & \multicolumn{2}{|c|}{ Male } & \multicolumn{2}{c}{ Female } \\
\cline { 2 - 5 } & Total & Enrolled & Total & Enrolled \\
\hline Primary (5-11) & 16.9 & 45.2 & 13.4 & 46.9 \\
\hline Secondary (12-17) & 10.3 & 7.1 & 6.5 & 0.7 \\
\hline
\end{tabular}

Source: PDMA and IRC 2015

Figure 2. Income Distribution of IDPs Before and After Displacement in Pakistani Rupees

$\square$ Before $\square$ After

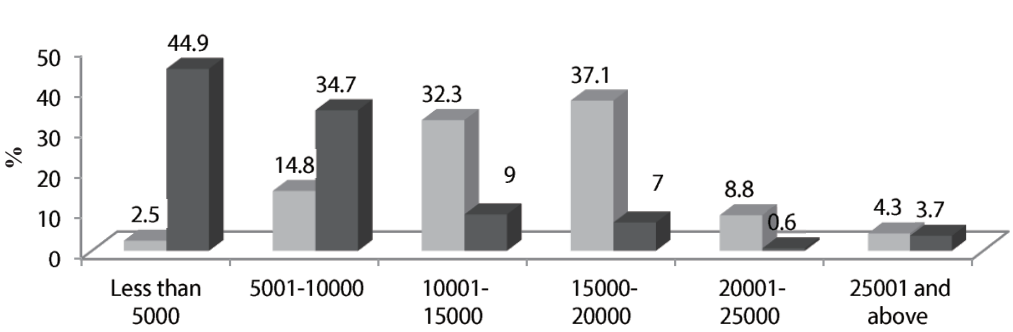

Source: Field Study in Jalozai Camp, 2015

Shemyakina 2007; Swee 2009; Justino 2010; Shields and Paulson, 2014) which indicate that girls have easy access to primary school, regardless of income, and that parents are supportive of education when girls are at a young age irrespective of customs and traditional barriers.

Table 2 provides enrolment figures broken down by gender, and shows that, among children of primary school age, 45.2 percent of males are enrolled while female enrolment in the same group is 46.9 percent. Among secondary schoolage children, 7.1 percent of boys and 0.7 percent of girls are enrolled. The results show that, at the primary school level, the gender ratio nearly equal, while at secondary level, which overall shows a drastic difference from the primary level in terms of overall enrolment, there are significantly more boys than girls. The reason for a lower number of females being enrolled is likely related to the strict customs and traditional values mentioned above; the main factor hindering male enrolment at the secondary level is child labor as seen below.

The results of survey questions on income are shown in Figure 2 and it can be seen that income disparity increased after conflict induced displacement with 44.9 percent of the population having income less than PKR \$ 5000 compared to only 2.5 percent with a similar income level before conflict and displacement. Whereas before displacement almost 70 percent of the respondents were in the PKR\$ 10,000-20,000 income range, a drastic change occurred after displacement 
Table 3. Changes in Source of Livelihood Before and After Displacement (\%)

\begin{tabular}{l|c|c}
\hline \hline \multicolumn{1}{c|}{ Livelihood source } & Before & After \\
\hline Agriculture/Livestock & 24.1 & 0.1 \\
Construction/Manufacturing & 16.2 & 26.8 \\
Transportation & 15.3 & 8.5 \\
Trade/Own Business & 19.3 & 4.6 \\
Government Job & 10.6 & 7 \\
Private Job & 7.5 & 19 \\
None/Unemployed & 1.6 & 29.5 \\
\hline Foreign Remittances & 5.4 & 4.3 \\
\hline
\end{tabular}

Source: Field Study in Jalozai Camp, 2015

Table 4. Child Labor Figures Before and After Displacement (\%)

\begin{tabular}{c|c|c}
\hline \hline & Before & After \\
\hline No & 96.5 & 75.0 \\
Yes & 3.5 & 25.0 \\
\hline
\end{tabular}

Source: Field Study in Jalozai Camp, 2015

with 80 percent of the respondents having less than PRK\$10,000 in income.

Furthermore, the decrease in the level of income can be understood in terms of a loss of property and land cultivation, privately owned businesses, trade connections, and vehicles to provide transportation services. After the outbreak of conflict, many households left all their belongings to urgently flee taking with them limited resources for sustaining their livelihood. Another factor which contributed to this decrease of income is that the refugee camp is far from cities where job opportunities may exist, thus limiting chances to earn income.

As seen in Table 3, the responses of IDPs in Jalozai Camp show that they were engaged in a variety of different economic sectors prior to their displacement including agriculture (24.1 percent), construction (16.2 percent), transportation (15.3 percent), managing personal businesses (19.3 percent), working in government positions (10.6 percent), and working in private enterprises (7.5 percent). After their displacement however, only 0.1 percent of households were engaged in agriculture with a similar pattern noticed in other sectors which require some form of property ownership. This resulted in a drop in income and this shift in sources of livelihood brutally affected education at both the primary and secondary school level.

Table 4 shows that child labor has significantly increased after displacement in Jalozai Camp, likely in an effort to increase income and contribute towards covering household expenses. Comparing the primary and secondary school levels, it has been observed that child labor is more prevalent at the secondary 
Table 5. Class Size Before and After Displacement (\%)

\begin{tabular}{l|c|c}
\hline \hline \multicolumn{1}{c|}{ Description } & Before & After \\
\hline 21-30 students & 6.0 & 3.5 \\
31-40 students & 49.5 & 33.0 \\
41-50 students & 38.5 & 54.5 \\
above 51 students & 6.0 & 9.0 \\
\hline
\end{tabular}

Source: Field Study in Jalozai Camp, 2015

Figure 3. Reasons Children Drop Out of School (\%)

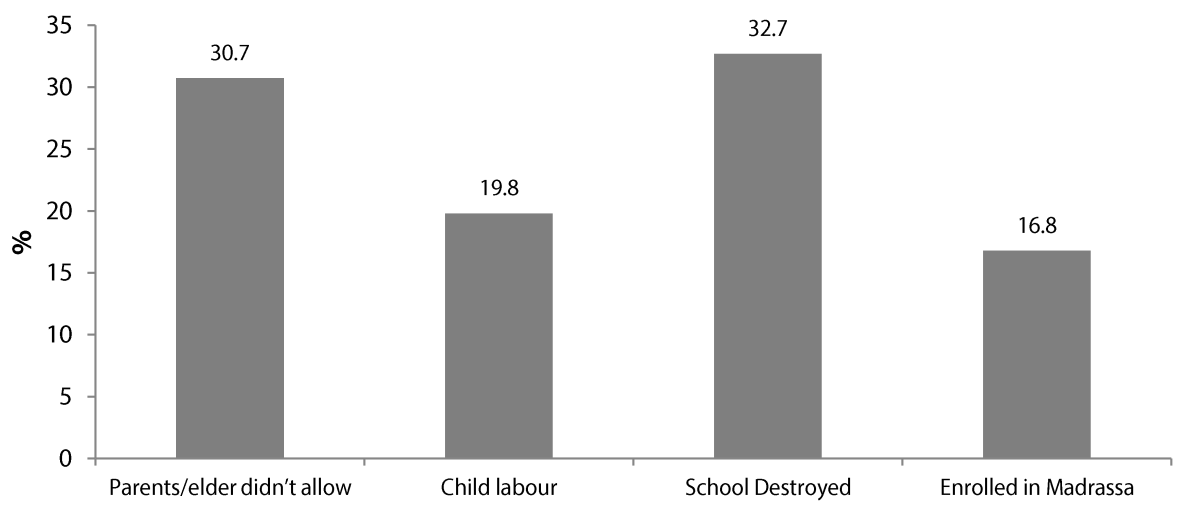

Source: Field Study in Jalozai Camp, 2015

school level, indicating that as the age of the child increases, the opportunity cost of schooling also increases. This is supported by the findings of Chamarbagwala and Moran (2011) who argue that, when conflict takes place, child labor increases towards lower returns to support the household, and it becomes very difficult for IDPs to support their families with most of the children, especially girls, unable to continue schooling at the secondary level.

The structure of social infrastructure shows that, after conflict and displacement, class size has increased for IDPs in school. Referring to Table 5 , before displacement 6 percent of students had classes with less than thirty students per class while 49.5 percent were in a class with between thirty-one and forty students and 38.5 percent of students were in a class with between fortyone and fifty students per class. The number of students per class increased substantially after moving to the refugee camp and, in some cases, class sizes have even reached 170 students in a single class. So, displacement has a significant impact on the perception of schooling with some people growing dissatisfied with the lack of standards governing the education in the area.

Thus barriers to schooling were not restricted to issues caused by conflict, but also consisted of problems that arose after displacement with another important 
factor contributing to the high dropout rate being the quality of schooling itself. Figure 3 indicates that 30.7 percent of children were not allowed by their parents/ elders to go to school, a key factor here being cultural norms on female education. Meanwhile, 32.7 percent of students indicated that they dropped out due to the loss of infrastructure and teacher availability, and 16.8 percent preferred joining a madrassa (Islamic religious school). Militants have targeted many schools with some having been partially destroyed and others completely destroyed. In analyzing the conflict in FATA, militants seemingly target schools to discourage education, thus leading many children to drop out even before displacement.

With regards to the type of school the children were attending, the results indicate that before displacement from FATA, a majority of the respondent's children were enrolled in government schools (68.9 percent) and private schools (31.1 percent). One of the important reasons for this was security concerns and NGO schools have not been well established in the troubled areas of FATA. During displacement, 87 percent of students were enrolled in NGO schools while among the remaining students 7.5 percent were in government schools and 5.5 percent were in private schools according to our field study.

The bulk of the students were in NGO schools because these tent based schools were easily accessible and do not charge any attendance fees. In the camp, emergency schooling was provided to the internally displaced children (IDC) to continue their studies during displacement. Another important reason for this is the fact that the camp is far from cities and accessibility to other schools or other facilities is poor. Therefore, IDPs were left with limited options and NGOs provided services at their doorstep in the camp which helped provide schooling in this emergency situation. However, an unfortunate fact is that these NGO schools find it difficult to provide classes during the summer due to the high heat, especially since their schools are mostly tents.

\section{Challenges and Barriers}

Evaluating the survey results from the demand side (household preference) and supply side (support from government, international NGOs, etc.), there are many factors which act as challenges or barriers to socio-economic progress and education in FATA. The results also help us understand the negative impacts on other sectors which have in turn directly and indirectly affect educational attainment.

On the demand side, before conflict erupted, income and livelihood opportunities were relatively better compared to the situation after internal displacement. As mentioned above, the primary reason was that property had to be left behind and there were limited sources of income around the camp. The results also indicate that cultural norms and traditions limit opportunities for 
females to attend secondary school and that the probability of getting a secondary education is lower for boys due to increases in the rates of child labor.

For instance, before displacement only 23 percent of respondents were not in favor of female education, but this intensified to 43.5 percent after displacement. There were no issues against primary education for girls, but roadblocks emerged as the girls grew older. Other studies have found similar results arguing that boys were given more attention than girls (Shemyakina 2007).

From the supply side perspective, results indicate that the number of secondary schools (two) was less than the number of primary schools (eight). The numbers clearly shows that the government, international NGOs, etc. have placed a higher priority on primary schooling compared to secondary schooling in Jalozai Camp. Moreover, in terms of the quality of schooling, most schools were tents with no boundary wall and limited facilities were available at both primary and secondary schools. The IDPs also seem to perceive that the quality of teaching was not satisfactory.

The common challenges from both the demand and supply sides include: extreme weather conditions, security threats, non-conducive environment for education, and limited transportation facilities in Jalozai Camp.

\section{Conclusion}

This article provides ample empirical evidence drawn from primary and secondary sources showing the negative impact of conflict on education. In Pakistan, insecurity and violent conflict represent key impediments to attaining the goals of universal primary and secondary education, this being an important focus of the Millennial Development Goals and now refined by Sustainable Development Goals. Although IDPs were exposed to many risks and deprivations in terms of sustaining livelihood and obtaining an education, this article concludes that displaced populations have faced problems maintaining old life patterns even after support from the government and donor agencies.

The study also concludes that common issues coupled with mistrust have hampered the efforts diverted towards integration into a community and towards facilitation. This study also identifies the increasing number of challenges as witnessed from both the demand and supply sides to schooling, livelihood, lowering of income and disparities, change of attitude, quality of schools, and other factors which has impacted the lives of the IDPs who were significantly impacted by conflict in their respective areas.

Considering the results illustrated above, several policy recommendations are noteworthy. First, it is necessary to encourage the UN-WFP "School Feeding Program" (SFP) to provide food rations to young IDPs in order to ensure they attend school. Second, special measures for increasing household income 
through an increased stipend rate are necessary to increase secondary enrolment and decrease child labor. Third, increased development budget allocation should be made to introduce scholarships for IDP children in FATA from government and donor agencies. Fourth, an effective monitoring system should be created for ensuring quality schooling, enrolment, and reducing supply side constraints. Finally, awareness should be raised on the relationship between conflict and education through an advocacy plan for increasing the priority of education and ensuring quality teaching.

\section{References}

Akbulut-Yuksel, Mevlude. 2009. "Children of War: The Long-Run Effects of Large-Scale Physical Destruction and Warfare on Children." HiCn Working Paper 62, September. http://www.hicn.org/wordpress/wp-content/uploads/2012/06/wp62.pdf (accessed February 11, 2016).

Akresh, Richard, and Damien de Walque. 2008. "Armed Conflict and Schooling: Evidence from the 1994 Rwandan Genocide." Policy Research Working Paper 406, World Bank, Develpoment Research Group, Human Development and Public Services Team, April. http://documents.worldbank.org/curated/en/368931468144008432/pdf/ WPS4606.pdf (accessed March 24, 2016).

Alderman, Harold, John Hoddinott, and Bill Kinsey. 2006. "Long term consequences of early childhood malnutrition." Oxford Economic Papers 58 (3): 450-474.

Boyden, Jo and Paul Ryder. 1996. "Implementing the Right to Education in Areas of Armed Conflict." University of Oxford, Department of International Development, June. https://www.essex.ac.uk/armedcon/story_id/000454.pdf (accessed May 18, 2017).

Brannelly, L., S. Ndaruhutse, and C. Rigaud. 2009. 'Donors' Engagement: Supporting Education in Fragile and Conflict-affected States. Paris: International Institute for Educational Planning and CfBT Education Trust.

Chamarbagwala, Rubiana, and Hilcias E. Moran. 2011. “The human capital consequences of civil war: Evidence from Guatemala." Journal of Development Economics 94 (1): 4161.

Chen, Siyan, Norman V. Loayza, and Marta Reynal-Querol. 2007. "The aftermath of civil war." World Bank Policy Reesearch Working Paper No. 4190, April. http://documents. worldbank.org/curated/en/879321468323968369/The-aftermath-of-civil-war (accessed February 6, 2016).

Chughtai, Muhammad Waqas. 2013. “The Impact of Rising Terrorism and Military Operations on Socio Economic Culture of Federally Administered Tribal Areas (FATA) of Pakistan." A Journal of Peace and Development 3 (1): 18-32.

Collier, Paul. 2007. The Bottom Billion. Oxford: Oxford University Press.

Crisp, Jeff. 2010. "Forced Displacement in Africa: Dimesions, Difficulties, And Policy Directions." Refugee Survey Quarterly 29 (3): 1-27.

Dorrien, Gary. 2001. The Making of American Liberal Theology. Louisville: Westminster John Know Press.

Dryden-Perterson, Sarah. 2010. Barriers to Accessing Primary Education in Conflict-Affected 
Fragile States. London: Save the Children.

Guariso, Andrea, and Marijke Verpoorten. 2013. "Armed conflict and schooling in Rwanda: Digging deeper." LICOS Discussion Paper Series, No. 343, November 6. https://www. econstor.eu/bitstream/10419/101056/1/770947328.pdf (accessed January 16, 2016).

Justino, Patricia. 2010. "War and Poverty." MICROCON Research Working Paper No. 32, August 28. https://papers.ssrn.com/sol3/papers.cfm?abstract_id=1666787 (accessed March 21, 2016).

Lai, Brian, and Clayton Thyne. 2007. "The Effect of Civil War on Educaton, 1980-97." Journal of Peace Research 44 (3): 277-292.

Mincer, Jacob. 1974. Schooling, Experience, and Earnings. New York: National Bureau of Economic Research.

Mooney, Erin, and Colleen French. 2005. "Barriers and Bridges: Access to Education for Internally Displaced Children.” The Brookings Institute-University of Bern, January 11. https://www.brookings.edu/research/barriers-and-bridges-access-to-educationfor-internally-displaced-children/ (accessed February 13, 2016).

Mustafa, Usman. 2013. "Detminants and Implications of Major Conflics in Pakistan." Millennial Asia 4 (1): 67-86.

PDMA (Provincial Disaster Management Authority) and IRC (International Rescue Committee). 2005. Personal Survey. Unpublished raw data.

Rice, Susan E., Corinne Graff, and Janet Lewis. 2006. "Poverty and Civil War: What Policymakers Need to Know. Brookings Global Economy and Development Working Paper, December 19. https://www.brookings.edu/research/poverty-and-civil-warwhat-policymakers-need-to-know/ (accessed February 19, 2016).

Shemyakina, Olga. 2006. "The Effect of Armed Conflict on Accumulation of Schooling: Resuls from Tajikistan.” HiCN Working Paper 12, November. http://www.hicn.org/ wordpress/wp-content/uploads/2012/06/wp12.pdf (March 15, 2016).

Shields, Robin, and Julia Paulson. 2014. “'Development in reverse'? A longitudinal analysis of armed conflict, fragility and school enrolment." Comparative Education 51 (2): 212230.

Swee, Eik Leong. 2011. "On War Intensity and Schooling Attainment: The Case of Bosnia and Herzegovina.” HiCN Working Paper 57, October. http://www.hicn.org/ wordpress/wp-content/uploads/2012/06/wp57.pdf (accessed January 24, 2016).

UNESCO. 2011. EFA Global Monitoring Report 2011: The hidden crisis: Armed conflict and education. Paris: UNESCO Publishing. http://unesdoc.unesco.org/ images/0019/001907/190743e.pdf (accessed March 15, 2016).

UNESCO. 2013. "Children still battling to go to school." Education for All Global Monitoring Report, Policy Paper 10, July. http://unesdoc.unesco.org/ images/0022/002216/221668E.pdf (accessed March 3, 2016).

UNHCR. 2009. "Refugees, Asylum-seeksers, Returnees, Internally Displaced and Stateless Persons." 2009 Global Trends, Division of Programme Support and Management, June 15. http://www.unhcr.org/statistics/country/4c11f0be9/2009-global-trendsrefugees-asylum-seekers-returnees-internally-displaced.html (accessed February 21, 2016).

UNICEF. 2009. The State of the World's Children, Special Edition: Celebrating 20 Years on the Convention on the Rights of the Child. New York: UNICEF. https://www.unicef. org/rightsite/sowc/pdfs/SOWC_Spec\%20Ed_CRC_Main\%20Report_EN_090409.pdf 
(accessed February 19, 2016).

UNICEF. 2013. Global inititiative on out-of-school children. https://www.unicef.org/ education/bege_61659.html (accessed March 10, 2016).

Anayat Ullah recently completed his M.Phil in Development Studies at the Pakistan Institute of Development Economics (PIDE), Islamabad in 2016. His areas of interest mainly include Conflict and Peace Education as well as Sustainable Livelihood and Governance. He has more than two years of experience working in the Ministry of Planning, Development and Reform as well as a UN-WFP project in KP, Pakistan. Email: au.shinwari@gmail.com

Karim Khan is an Assistant Professor at the Pakistan Institute of Development Economics, Islamabad, Pakistan. He received his M.A. in Economics from the University of Peshawar, Pakistan. He got his M.Phil in Economics from Quaid-i-Azam University, Islamabad, Pakistan and his Ph.D. in Economics from the University of Siena, Italy. He is working in the fields of Institutional Economics, Political Economy, and Experimental Economics and has published in journals like Constitutional Political Economy, the Journal of Economics and Econometrics, Humanomics, Pakistan Development Review, the Lahore Journal of Economics, etc. Email: karim.khan@pide.org.pk

Hamid Mahmood has been working as an Assistant Chief/Economic Adviser in the Ministry of Planning, Development, and Reform, Planning Commission, Islamabad since 2008. He has served in different sections including Trade and Finance, Sustainable Development and Climate Change, Macroeconomics, and Public Investment Programming, and contributed to the New Growth Strategy approved by the Prime Minister in 2011. His areas of interest include Sustainable Development, Trade Facilitation and Integration, Peace and Conflict, Building, Inclusive Economic Growth and Social Sector Development with publications in peered reviewed scientific journals to his name. Email: hamidm03@gmail.com 